\title{
セラミックス系薄膜合成用ラジカルビーム源の 試作と評価
}

\author{
今井 文一・国森 公夫・野副 尚一* \\ 筑波大学物質工学系（⿶305 つくば市天王台 1-1-1 \\ * 物質工学工業技術研究所 函305 つくば市東 1-1
}

(1994 年 7 月 20 日受付, 1994 年 9 月 12 日掲載決定)

\section{Development and Characterization of a Radical Beam Source for the Synthesis of Ceramic Thin Films}

\author{
Fumikazu Imai, Kimio Kunimori and Hisakazu Nozoye* \\ Institute of Materials Science, University of Tsukuba \\ 1-1-1 Tennodai, Tsukuba, Ibaraki 305 \\ * National Institute of Materials and Chemical Research \\ 1-1 Higashi, Tsukuba, Ibaraki 305
}

(Received July 20, 1994 : Accepted September 12, 1994)

\begin{abstract}
We developed a newly designed radical beam source for the synthesis of high quality ceramic thin films. Radical species were generated by an electrodeless radio frequency discharge of 13.56 $\mathrm{MHz}$. We succeeded in generation of stable atomic oxygen beam which contained few ionic species. Intensity of the beam was as high as $1.4 \times 10^{16}$ atoms $/ \mathrm{cm}^{2} \cdot \mathrm{s}$ at $5 \mathrm{~cm}$ from the end of beam source. Epitaxial thin films of anatase form of $\mathrm{TiO}_{2}$ and TiN were synthesized on $\mathrm{MgO}$ (100) single crystal substrates by using oxygen radical beam and nitrogen radical beam, respectively.
\end{abstract}

\section{1.はじめに}

近年セラミックス系薄膜の合成手法として, 酸素や窒 素などのラジカル種を利用した反応性蒸着法が注目され ている。これまでの反応性蒸着法では, 反応ガスとして $\mathrm{O}_{2}{ }^{1)}$ をじめとして $, \mathrm{O}_{3}{ }^{21}, \mathrm{NO}_{2}{ }^{3}, \mathrm{~N}_{2} \mathrm{O}^{4)}, \mathrm{NH}_{3}{ }^{5)}$ など が用いられてきた。しかしそれらの気体は毒性を伴うた めその取り扱いには注意を必要とし，より安全かつ高効 率での薄膜合成を可能にする新たな手法が求められてき た。そこでそれらの分子状気体に代わる新たなガスソー スとして，気体放電によって生成するプラズマの利用が 考えられるようになった。てれまでに DC 放電 ${ }^{6,7)}, \mathrm{RF}$ 放電 ${ }^{8-10)}, \mathrm{ECR}$ 放電 ${ }^{11 \sim 13)}$ な゙゙を利用した種々のプラズ マビーム源が開発され，すでに半導体の分野では，薄膜 の酸化やクリーニングなどを目的とした ECR イオン源 などが用いられている。しかしてれらの装置は低真空中
での動作を必要とするために薄膜表面が残留ガスなどに 污染されやすく，また荷電粒子による表面ダメージなよ゙ をひきおてすために高品質なセラミック系薄膜の合成に は向いていなかった。

そてでわれわれは高品質なセラミックス系薄膜の合成 を目的とした，イオン種を含まない高出力中性ラジカル ビーム源を試作し，薄膜合成に及ぼす効果について検討 した。

\section{2. 試作}

Fig. 1 亿今回試作したラジカルビーム源の模式図を 示す。本体の主な構成部品は, アルミナ製放電管, PBN 製エンドプレート，銅製誘導結合式放電コイル，ステン レス製シールドである。また放電管内壁材質が酸素ラジ カルビーム強度に及ぼす効果について, 石英, ほう酸で コーティングした石英, PBN の 3 種類の材質を用いて 


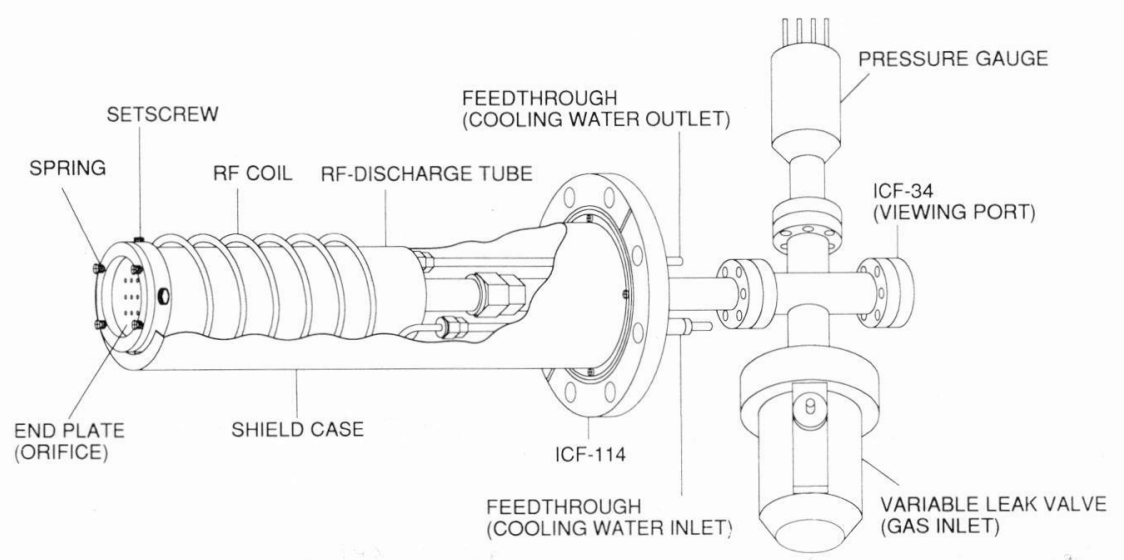

Fig. 1 Schematic diagram of the radical beam source.

検討した結果，PBN を用いたときに最も強い中性ラジ カルビームを発生できることがわかった ${ }^{14)}$ 。そのため今 回の実験では PBN 製のスリーブを放電管内に插入し た。ラジカルビーム源の高真空中での動作を可能にする ためには，放電管内老低真空 $(0.1 \sim 1.0$ Torr $)$ に保ち放 電老継続させ，エンドプレートに開けたオリフィスから 効率よくビーム在照射させる必要がある。真空中での シール材としてバイトンの○リングが広く用いられてい るが， $150^{\circ} \mathrm{C}$ 以上では徐々に分解することが知られてい る。放電中のラジカルビーム源先端部の温度を測定した

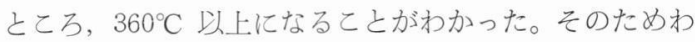
れわれの装置では，エンドプレートを放電管開口部側に スプリングで押し付ける面シールの手法を用いるととに よって, エンドプレートの縁からの漏れをオリフィス を通過する全流量の $1 / 10$ 程度まで減らすととに成功し た。

\section{3. 評 価}

バリアブルリークバルブを介して放電管内にガスを導 入し， $13.56 \mathrm{MHz}$ の高周波をコイルに供給して放電さ せた。放電の様子はビームソース後端に取り付けたビュ 一ポートより観察し, シリコンフォトダイオードを用い て $190 \mathrm{~nm}$ から $1100 \mathrm{~nm}$ の全発光強度測定と, マルチ チャンネルアナライザーによる $300 \mathrm{~nm}$ から $800 \mathrm{~nm}$ の 発光スペクトル分析を行った。

酸素プラズマの放電の様子は放電管内に導入する酸素 の圧力によって大きく変化した。放電管内圧力が約 0.3 Torr から 0.5 Torr のとき, 全発光強度は最も強くな り, 赤紫色の酸素プラズマの生成か確認された。またと のときの蒸着装置内の真空度は $10^{-6}$ Torr 台であった。

Fig. 2 に酸素プラズマの発光スペクトルを示す。777.4 $\mathrm{nm}$ に原子状酸素( $\left.\mathrm{O}^{*}\right)$ に上る非常に強い輝線スペクト

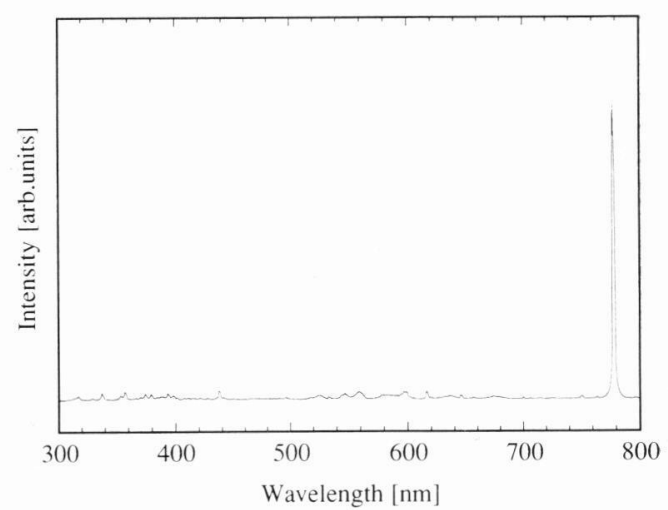

Fig. 2 Emission spectra of oxygen plasma discharged in the beam source at $450 \mathrm{~W}$ of $\mathrm{rf}$ power.

ルが観察された。ほかに酸素分子イオン $\left(\mathrm{O}_{2}{ }^{+}\right)$などあ観 察されたが，それらのスペクトルの $777.4 \mathrm{~nm}$ に現れる 輝線スペクトルに対する相対強度は $3 \%$ 以下であった。 水晶膜厚計上に蒸着した銀薄膜の酸化に伴う質量変化を 計測し，ビーム强度を計算した結果，ラジカルビーム 先端から $5 \mathrm{~cm}$ の位置で $1.4 \times 10^{16} \mathrm{atoms} / \mathrm{cm}^{2} \cdot \mathrm{s}$ 以上の 原子状酸素ラジカルビームが発生していることがわかっ た。またそのときのイオン電流密度を測定したところ, $10^{12} \mathrm{ions} / \mathrm{cm}^{2} \cdot \mathrm{s}$ 以下であるととがわかった ${ }^{14)}$ 。

窒素プラズマも酸素プラズマ同様に, 放電管内压力が 約 0.5 Torr のときに最む強い赤燈色の発光が観測され た。窒素プラズマの場合, 酸素プラズマに比較して非常 に多くの発光スペクトルが得られた (Fig. 3)。それら のスペクトルは窒素ラジカル $\left(\mathrm{N}_{2}{ }^{*}, \mathrm{~N}^{*}\right)$, 窒素分子イオ ン $\left(\mathrm{N}_{2}{ }^{+}\right)$に帰属することができ, 最む強い $357.8 \mathrm{~nm}$ のスペクトルは窒素ラジカル $\left(\mathrm{N}_{2}{ }^{*}\right)$ によるあのである ととがわかった。 


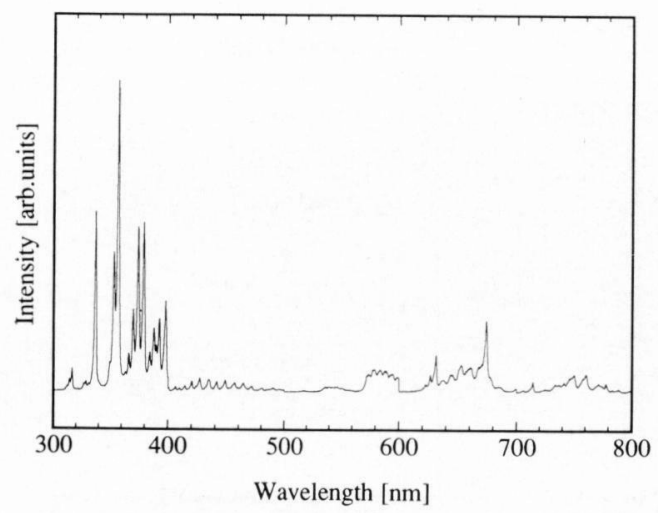

Fig. 3 Emission spectra of nitrogen plasma discharged in the beam source at $450 \mathrm{~W}$ of $\mathrm{rf}$ power.

\section{4. 応用}

薄膜の合成は, ベース真空度 $2 \times 10^{-7}$ Torr の真空蒸 着装置内で行った。基板には $10 \times 10 \times 1 \mathrm{~mm}^{3}$ の単結晶 $\mathrm{MgO}$ (100) 基板を用いた。基板表面温度 $380^{\circ} \mathrm{C}$ で 1 時間 脱ガスの後, 電子ビーム蒸着源よりチタンを $0.05 \mathrm{~nm} / \mathrm{s}$ で連続蒸着しながら酸素, 窒素, およびそれぞれのラジ カルビームを照射した。チタンの蒸着膜厚はいずれの場 合も $100 \mathrm{~nm}$ とした。薄膜の成長過程は RHEED で観 察し, XRD でキャラクタリゼーションを行った。

われわれは以前，パルス分子線交互蒸着法を用いて単 結晶 $\mathrm{MgO}(100)$ 基板上に酸化チタン薄膜の合成を行い, 酸素欠陥のために結晶格子が下地の影響を受けた (100) 配向の疑似アナターゼ型二酸化チタンがエピタキシャル 成長するととを見出した ${ }^{15)}$ 。本研究においてチタンと純 酸素の連続蒸着法で薄膜を合成した結果，結晶性は悪い あののやはり (100) 配向した疑似アナターゼ型二酸化于 タン薄膜が生成することがわかった。合成した薄膜は酸 素欠陥により濃紺色であった。そこで純酸素より酸化効 率が高いと考えられる酸素ラジカルビームを用いて，同 様の連続蒸着法で酸化チタン薄膜を合成した。合成した 薄膜は淡黄色透明であり, XRD 測定した結果, $48.26^{\circ}$ と $109.24^{\circ}$ にピークを認めることができ，乙れらはそれ ぞれアナターゼ型二酸化チタンの (200) 回折線（面間 隔 $1.892 \AA$ ) および (400) 回折線 (面間隔 $0.9464 \AA$ ) に よく一致し，(100) 配向したアナターゼ型二酸化チタン であるととがわかった（Fig．4）。またその XRD ピー ク強度む純酸素ビームを用いて合成した薄膜と比較して 10 倍以上強く, 結晶性の良い良質なエピタキシャル薄 膜が合成できるととがわかった。

窒素ラジカルを用いて窒化チタン薄膜を合成した場

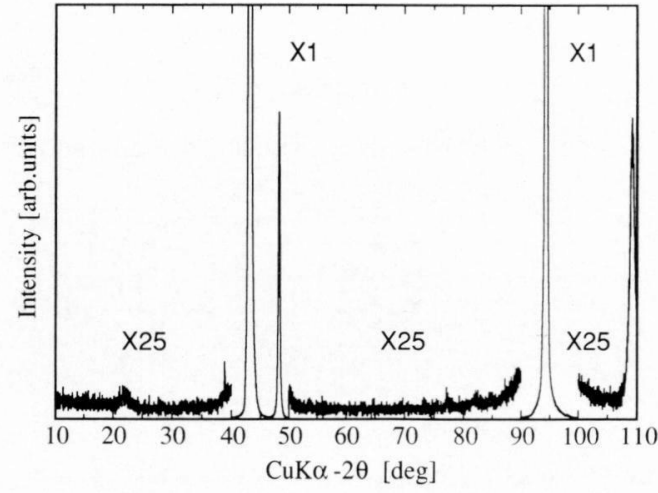

Fig. 4 XRD pattern of titanium oxide thin film synthesized on $\mathrm{MgO}(100)$ single crystal substrate by using oxygen radical beam.

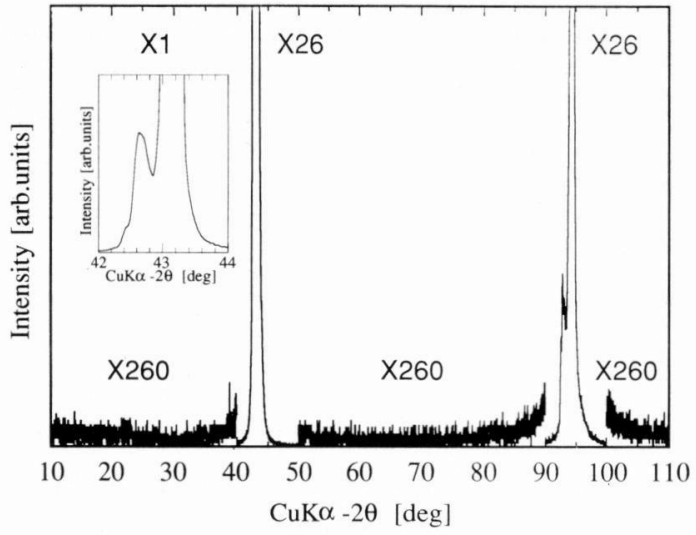

Fig. 5 XRD profiles of titanium nitride thin film synthesized on $\mathrm{MgO}(100)$ single crystal substrate by using nitrogen radical beam.

合，合成中継続して基板と同じ RHEED ストリークパ ターンが観察された。XRD 測定した結果， $42.64^{\circ}$ と $92.80^{\circ}$ Kピークが認められ，それぞれ窒化チタン ( TiN) の (200) 回折線（面間隔 $2.1207 \AA$ ) および (400) 回折 線（面間隔 $1.0604 \AA$ ) と非常によく一致した (Fig. 5)。 一方純窒素を用いて薄膜を合成した場合，ディフューズ な RHEED パターンが観測され，XRD 測定により面間 隔 $2.10 \AA$ と $1.05 \AA$ に相当するピークが観測された。 これらのピークは窒素ラジカルを用いて合成した薄膜と 同様に TiN に帰属できると考えられるが，基板の $\mathrm{MgO}$ 格子の影響を受けて面間隔が小さくなる方向へシ フトしていることがわかる。 TiN は $\mathrm{MgO}$ と同じく岩 塩型結晶構造を形成し, またその格子定数 $(a=4.242 \AA)$ 屯 $\mathrm{MgO}$ の值 $(a=4.213 \AA)$ と非常に近いため, 酸化于 タンと比較して $\mathrm{MgO}$ 基板上にエピタキシャル成長し やすいととが推測される。 


\section{5. まと め}

セラミックス薄膜合成を目的としたラジカルビーム源 を開発した。イオン種をほとんど含まない中性ラジカル ビームを発生させることに成功し, 高品質な酸化チタン 薄膜, 窒化チタン薄膜の合成に有効であることがわかっ た。

\section{文 献}

1) T. Terashima and Y. Bando: J. Appl. Phys. 56, 3445 (1984).

2) D. D. Berkley, B. R. Johnson, N. Anand, K. M. Beauchamp, L. E. Conroy, A. M. Goldman, J. Maps, K. Mauersberger, M. L. Mecartney, J. Morton, M. Tuominen and Y.-J. Zhang: Appl. Phys. Lett. 53, 1973 (1988).

3) S. Watanabe, M. Kawai and T. Hanada: Jpn. J. Appl. Phys. 29, L 1111 (1990).

4) A. Gupta and B. W. Husse : Appl. Phys. Lett. 58, 1211 (1991).

5) S. Yoshida, S. Misawa and A. Itoh: Appl. Phys. Lett. 26, 461 (1975).

6) J.B. Beck and J. Ruzyllo: Thin Solid Films 136, 173 (1986).
7) A. Schuhl, R. Cabanel, S. Lequien, B. Ghyselen, S. Tyc, G. Creuzet and J. Siejka : Appl. Phys. Lett. 57, 819 (1990).

8) T. Terashima, K. Iijima, K. Yamamoto, $Y$. Bando and H. Mazaki : Jpn. J. Appl. Phys. 27, L 91 (1988).

9) K. Yamauchi, K. Takahashi and E. Yabe : Rev. Sci. Instrum. 64, 2434 (1993).

10) R. M. Silver, A. B. Berezin, M. Wendman and A. L. de Lozanne: Appl. Phys. Lett. 52, 2174 (1988).

11) A. Asmussen, R. Fritz, L. Mahoney, G. Fournier and G. Demaggio: Rev. Sci. Instrum. 61, 282 (1990).

12) P. O’Keeffe, S. Komuro, S. Den, T. Morikawa and Y. Aoyagi: Jpn. J. Appl. Phys. 30, 3164 (1991).

13) T. Aida, A. Tsukamoto, K. Imagawa, T. Fukazawa, S. Saito, K. Shindo, K. Takagi and K. Miyauchi : Jpn. J. Appl. Phys. 28, L 635 (1989).

14) F. Imai, K. Kunimori and H. Nozoye : J. Vac. Sci. Technol., submitted.

15）今井文一, 倉持宏実, 国森公夫, 内島俊雄, 近 藤 寛, 新藤 斎, 野副尚一：表面科学 $13(5), 266$ (1992). 